Brazilian Journal
of Chemical
Engineering

ISSN 0104-6632

Printed in Brazil

www.abeq.org.br/bjche

Vol. 25, No. 03, pp. 435 - 442, July - September, 2008

\title{
ELECTROFLOTATION OF EMULSIFIED OIL IN INDUSTRIAL WASTES EVALUATED WITH A FULL FACTORIAL DESIGN
}

\author{
F. N. B. Nahui ${ }^{1}$, M. R. Nascimento ${ }^{2}$, E. B. Cavalcanti ${ }^{3}$ and E. O. Vilar ${ }^{4 *}$ \\ ${ }^{1}$ Universidade Federal de Campina Grande, Unidade Acadêmica de Mineração e Geologia, \\ Phone: +(55) (83) 3310-1314, Fax: +(55) (83) 3310-1114, Av. Aprígio Veloso 882, \\ CEP 58109-970, Campina Grande - PB, Brazil, \\ E-mail: flora@yahoo.com \\ ${ }^{2}$ Escola Agrotécnica Federal de Sousa, PB EAFS-PB, Rua Presidente Tancredo Neves, s/n, \\ CEP: 58.805 970, Jardim Sorrilândia, Sousa - PB, Brazil. \\ E-mail: marceloquimica@gmail.com \\ ${ }^{3}$ Instituto de Tecnologia e Pesquisa, ITP, Universidade Tiradentes, UNIT, \\ Av Murilo Dantas 300, CEP: 49032-490, Farolândia, Aracajú - SE, Brazil. \\ E-mail: eliane@itp.org.br \\ ${ }^{4}$ Universidade Federal de Campina Grande, Unidade Acadêmica de Engenharia Química, \\ Laboratório de Engenharia Eletroquímica, Phone: +(55) (83) 3310-1314, \\ Fax: +(55) (83) 3310-1114, Av. Aprígio Veloso 882, \\ CEP 58109-970, Campina Grande - PB, Brazil, \\ E-mail: oliveiravilar@gmail.com
}

(Received: February 1, 2007 ; Accepted: February 28, 2008)

\begin{abstract}
The use of electroflotation in emulsified oil wastes was studied. A rectangular electroflotation cell was designed and constructed in acrylic with stainless steel cathode and DSA ${ }^{\circledR}$ anode with a nominal composition of $\mathrm{Ti} / \mathrm{Ru}_{0.34} \mathrm{Ti}_{0.66} \mathrm{O}_{2}$. The variables studied in the present work were current density and oil, flocculant and electrolyte $(\mathrm{NaCl})$ concentrations. The experiments were carried out in accordance with $2^{4}$ full factorial experimental designs with two center points. The STATISTICA 5.5 software was used for calculations in order to relate experimental data to a statistical model. The best results, yielded $99.71 \%$ oil removal were obtained from 1050ppm of emulsified oil feed.

Keywords: Electroflotation; Emulsified oil; Industrial waste water; Factorial design.
\end{abstract}

\section{INTRODUCTION}

The development of new techniques for treatment of wastewater with high salinity from the petroleum industry has been a challenge due to the increase in production in Brazil. Voluntary or involuntary spilling of oil in different kinds of water is an issue of environmental concern. The high salinity and large volumes normally involved prevent the use of traditional biological processes. Conventional biological processes are there ruled out due to the requirement of large plant and skilled technicians. In the electroflotation process, bubbles are generated by water electrolysis (Chen et al, 2002 and Ben Mansur et al, 2006) to produce hydrogen and oxygen at the cathode and anode respectively. Compared with conventional flotation, electroflotation has many advantages. Firstly, it is characterized by a fast rate of removal pollutant particles. Secondly, it is able to achieve simultaneous flotation and coagulation, with less sludge produced. Thirdly, the electroflotation equipment is very compact and thus suitable for installation where the available space is rather limited. Furthermore, the convenience of dosing

*To whom correspondence should be addressed 
control only by adjusting the current makes automation quite easy operation and offers simplicity and low capital and operating costs (Hosny et al, 1992 Calvin et al, 1997). Recently, Ben Mansur and Chalbi (2006) examined the effect of operating parameters such as current density, oil concentration, flotation time and coagulant concentration on the performance of the electroflotation cell. Oil removal reached $70 \%$ under optimum conditions $75 \%$ with $\mathrm{NaCl}(3.5 \%$ by wt) and $99.5 \%$ with both $\mathrm{NaCl}$ and an optimum concentration of coagulant. Electrical energy consumption varied from 0.4 to $1.6 \mathrm{kWhm}^{-3}$ under the experimental conditions. The performance of the oil removal process was also represented by a first-order kinetic model. The constants obtained fit the experimental data well. The electroflotation mechanism for wastewater treatment is very complex. It is generally believed that there are other possible mechanisms involved besides electroflotation, i.e. electrocoagulation, electrochemical oxidation and adsorption. Nevertheless, all the mechanisms highly depend on charge loading (Koren et al, 1995). A few studies applied an insoluble anode for removal processes (Kholsa et al, 1991 and Chen et al, 2000). The electrode assembly is the heart of the present treatment facility. Therefore, careful selection of its materials is very important. The most common electrode materials for electroflocculation are aluminum and iron (Khosla et al, 1991 and Chen et al, 2000).

In general most optimization studies during the development of a process involve varying one factor at a time, keeping other factors constant. Factorial designs conducted in a completely randomized manner enable all factors to be varied simultaneously, thus allowing quantification of the effects caused by independent variables and interactions between them. Another important advantage is that experimental designs can be changed progressively until a fitted model is found to describe the studied phenomenon. This article evaluates the effect of four parameters on electroflotation of emulsified solution using the factorial experimental design. Statistical models to quantity the effect of these parameters, individually and/or jointly, were determined.

\section{MATERIALS AND METHOD}

A rectangular electroflotation cell was constructed of acrylic with the dimensions $8 \mathrm{~cm} \times 9$ $\mathrm{cm}$ and a height of $30 \mathrm{~cm}$. Stainless steel and DSA ${ }^{\circledR}$ $\left(\mathrm{Ti} / \mathrm{Ru}_{0.34} \mathrm{Ti}_{0.66} \mathrm{O}_{2}\right)$ both expanded materials connected in a monopolar mode were used as cathode and anode, respectively. The electrodes were positioned horizontally at the bottom of the cell. The gap between the electrodes was $1.5 \mathrm{~cm}$. The cathode and anode areas of $98.3 \times 10^{-4} \mathrm{~m}^{2}$ and $154 \times 10^{-4} \mathrm{~m}^{2}$, respectively, were calculated using the Image Tool version 1.2 software. A schematic diagram of the experimental set-up is shown in Figure 1 . The synthetic emulsions $(350 \mathrm{mg} / \mathrm{L})$ was prepared from diesel oil (Petrobrás Company) and Tween 20 as emulsifier from Oxiteno S.A.. The emulsion volume in the cell was $1.5 \mathrm{~L}$. The $\mathrm{pH}$ was adjusted to 4.5 with $\mathrm{HCl}$. In order to examine the effect of salinity on oil removal efficiency, $\mathrm{NaCl}$ was added to synthetic emulsions to vary their conductivity. The flocculant used was a polyelectrolyte ironsalt from Clarient S.A. An electroflotation time of 30 min was utilized. After process, the cell was cleaned carefully to remove any oil contamination. The potential applied and current obtained were measured by a digital DC power supply model CA-CG EMG. The concentrations of oil before and after electrolysis were measured with a Hach DR/2000 spectrophotometer.

A four-factor, two-level $\left(2^{4}\right)$ factorial design which corresponds to 16 different experiments was established. Two additional curves, for which the values variables is determined by the central point, were used (see Table 2: experiments no 17 and 18). Based on the data obtained using this experimental design, equations were generated to establish the correlation between the independent variables (i.e., oil, flocculant and electrolyte $(\mathrm{NaCl})$ concentrations and current density) and the dependent variables (i.e., percentage oil removal and energy consumption). The equations were validated by the following statistical tests: Analysis of variance (ANOVA) was used to determine the significance of each term in the equations fitted and to estimate the goodness of fit in each case. The calculated F-value was compared to the theoretical F-value, $\mathrm{F}_{\alpha}(\mathrm{p}-1$, n$\mathrm{p})$, where $\alpha$ is the chosen risk, set in this study at $0.05 ; \mathrm{n}$ is the total number of experiments and $\mathrm{p}$ is the number of terms in the model and explained variance $(\%)$. The response surface methodology (RSM) was used to analyze the experimental design. The response variable was fitted by a first-order model in order to correlate the response to the respective independent variables. The general form of the first-degree equation is

$\mathrm{Y}_{\mathrm{i}}=\beta_{0}+\sum \beta_{\mathrm{i}} \mathrm{x}_{\mathrm{i}}+\sum \beta_{\mathrm{ij}} \mathrm{x}_{\mathrm{i}} \mathrm{x}_{\mathrm{j}}$ 
where $Y_{i}$ is the predicted response, $x_{i}$ and $x_{j}$ are input variables which affect variable $Y$ and $\beta_{0}$ is the offset term and $\beta_{\mathrm{i}}$ is the ith linear coefficient; $\beta_{\mathrm{ij}}$ is the ijth interaction coefficient. The coefficients were calculated using the STATISTIC software (version 5.5).

From experimental observations, it was assumed that the higher order interactions were small relative to the low order interactions because a system with several process variables is conducted primarily by some of the main effects and low-order interactions. Therefore, the present work considers only two-way interactions. The other higher order interactions were added into the error. The center points could be used to check the curvature in the model to be fitted. The main variables $X_{\mathrm{oil}}, \mathrm{X}_{\mathrm{floc}}, \mathrm{X}_{\mathrm{NaCl}}$ and $\mathrm{X}_{\mathrm{i}}$ represent oil, flocculant, electrolyte concentration and current density, respectively. The levels for the four main variables were chosen from our previous experiments. The original values of the variables are shown in Table 1.

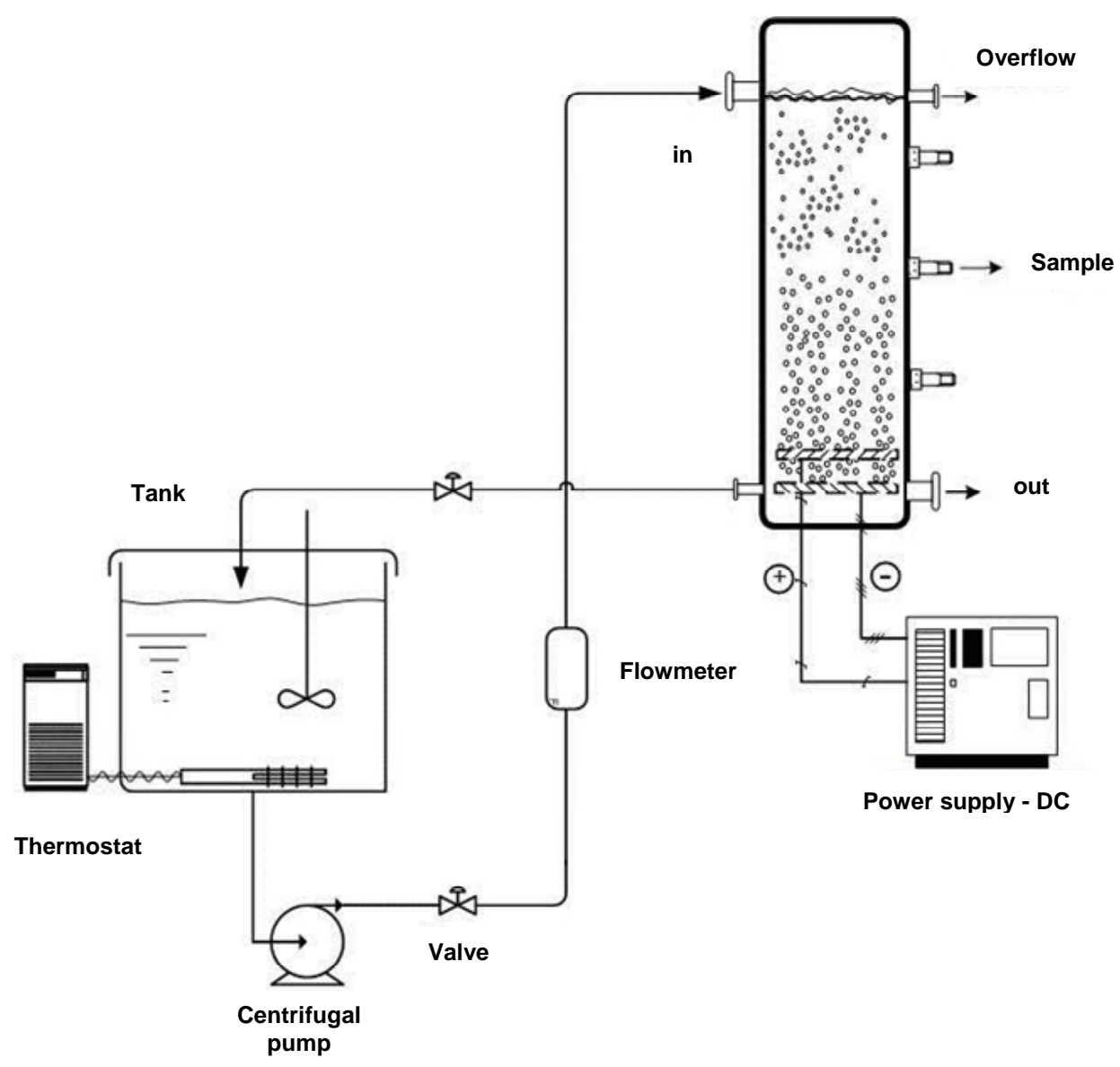

Figure 1: Schematic diagram of the system.

Table 1: Original variables.

\begin{tabular}{|l|c|r|r|r|}
\hline Main variable & Original variable(X) & $\mathbf{- 1}$ & $\mathbf{0}$ & $\mathbf{+ 1}$ \\
\hline [oil] ppm & $\mathrm{X}_{\text {oil }}$ & 200 & 625 & 1050 \\
[floc] ppm & $\mathrm{X}_{\text {floc }}$ & 4 & 18 & 32 \\
i A m & $\mathrm{X}_{\mathrm{i}}^{-2}$ & 19.48 & 126.62 & 233.76 \\
{$[\mathrm{NaCl}] \mathrm{ppm}$} & $\mathrm{X}_{\mathrm{NaCl}}$ & 15000 & 25000 & 35000 \\
\hline
\end{tabular}




\section{RESULTS AND DISCUSSION}

The matrix of experiments and results are presented in Table 2. The corresponding analysis of variance (ANOVA) is presented in Table 3. The calculated Fvalue is greater than the tabulated $\mathrm{F}$-value, $\mathrm{F}_{0.95,1,7}=$ 3.64 at $\alpha=0.05$ level so the null hypothesis $\left(\mathrm{H}_{0}\right)$ is rejected. Having rejected the null hypothesis, it can be inferred that treatment differences are highly significant. Also, the high F-value and a very low probability indicate that the present model provides a good prediction a experiments results (as a practical rule, a model has statistical significance when the calculated F-values are at least three to five times greater than the tabulated F-values) (Barros et al, 1996).

The variables chosen for the optimization procedure are those that could affect the percentage oil removal. The main and interaction effects of the four variables are given in Table 4.

The significant effects are indicated in boldface. It was observed that the flocculant concentration does not have statistical significance $\left(\alpha_{\text {floc }}=0.4549\right)$ for oil removal, but it is important to the flocculation process (Hosny, 1992, 1996; Ben Mansur and Chalbi, 2006). Therefore if we take the statistical point of view we can eliminate the $X_{\text {floc }}$ variable column presented in Table 2 and proceed through the $2^{3}$ experimental factorial analysis. In the same Table 4 , it can also be observed that the effect of flocculant and oil concentrations on energy consumption is not statistically significance $\left(\alpha_{\text {oil }}=0.844\right.$ and $\alpha_{\text {floc }}=$ $0.92)$, so we can simplify the model by eliminating the $\mathrm{X}_{\mathrm{oil}}$ and $\mathrm{X}_{\mathrm{oil}}$ and $\mathrm{X}_{\text {floc }}$ variable columns in Table 2 an repeat the $2^{2}$ four times experimental factorial design (Rodrigues and Lemma, 2005). In Table 5 the new results of variance measurements are shown.

Table 2: $2^{4}$ full factorial experiment design with two center points.

\begin{tabular}{|c|c|c|c|c|c|c|}
\hline Experiment & $\mathbf{X}_{\text {oil }}$ & $\mathbf{X}_{\text {floc }}$ & $\mathbf{X}_{\mathbf{i}}$ & $\mathbf{X}_{\mathbf{N a C l}}$ & $\begin{array}{c}\text { Oil removal } \\
\text { percentage }\end{array}$ & $\begin{array}{c}\text { Energy consumption } \\
\left(\mathbf{k W h} / \mathbf{m}^{\mathbf{3}}\right)\end{array}$ \\
\hline 1 & -1 & -1 & -1 & -1 & 75.00 & 0.2 \\
2 & +1 & -1 & -1 & -1 & 95.33 & 0.173 \\
3 & -1 & +1 & -1 & -1 & 82.50 & 0.206 \\
4 & +1 & +1 & -1 & -1 & 96.57 & 0.18 \\
5 & -1 & -1 & +1 & -1 & 93.00 & 4.56 \\
6 & +1 & -1 & +1 & -1 & 98.66 & 4.52 \\
7 & -1 & +1 & +1 & -1 & 93.50 & 4.52 \\
8 & +1 & +1 & +1 & -1 & 98.76 & 4.48 \\
9 & -1 & -1 & -1 & +1 & 91.00 & 0.163 \\
10 & +1 & -1 & -1 & +1 & 98.76 & 0.167 \\
11 & -1 & +1 & -1 & +1 & 92.00 & 0.167 \\
12 & +1 & +1 & -1 & +1 & 97.43 & 3.36 \\
13 & -1 & -1 & +1 & +1 & 96.00 & 3.28 \\
14 & +1 & -1 & +1 & +1 & 99.62 & 3.32 \\
15 & -1 & +1 & +1 & +1 & 97.00 & 1.32 \\
16 & +1 & +1 & +1 & +1 & 99.81 & 1.54 \\
\hline 1 & 0 & 0 & 0 & 0 & 99.04 & \\
\hline
\end{tabular}

Table 3: Analysis of variance (ANOVA) for percentage oil removal and energy consumption.

\begin{tabular}{|l|c|c|}
\hline \multicolumn{1}{|c|}{ Statistical analysis } & $\begin{array}{c}\text { Oil removal } \\
\text { percentage }\end{array}$ & $\begin{array}{c}\text { Energy consumed } \\
\left(\mathbf{k W}-\mathbf{h} / \mathbf{m}^{\mathbf{3}}\right)\end{array}$ \\
\hline Explained variance (\%) & 89.93 & 99.22 \\
Correlation coefficient & 0.9349 & 0.9942 \\
Calculated F-value & 6.20 & 89.24 \\
Tabulated F-value (CI=95\%) & 3.64 & 3.64 \\
Calculated F/Tabulated F & 1.70 & 24.51 \\
\hline
\end{tabular}


Table 4: The main and interaction effects of the four variables.

\begin{tabular}{|l|c|c|}
\hline Variables & Percentage oil removal & $\begin{array}{c}\text { Energy consumed } \\
\left(\mathbf{k W h} / \mathbf{m}^{\mathbf{3}}\right)\end{array}$ \\
\hline Mean & 94.84 & 1.96 \\
$\mathrm{Y}_{\text {oil }}$ & 8.11 & -0.02 \\
$\mathrm{Y}_{\text {floc }}$ & 1.27 & -0.01 \\
$\mathrm{Y}_{\mathrm{i}}$ & 5.97 & 3.74 \\
$\mathrm{Y}_{\mathrm{NaCl}}$ & 4.78 & -0.61 \\
$\mathrm{Y}_{\text {oil }} \mathrm{Y}_{\text {floc }}$ & -1.22 & 0.009 \\
$\mathrm{Y}_{\text {oil }} \mathrm{Y}_{\mathrm{i}}$ & -3.78 & -0.01 \\
$\mathrm{Y}_{\text {oil }} \mathrm{Y}_{\mathrm{NaCl}}$ & -3.21 & 0.007 \\
$\mathrm{Y}_{\text {floc }} \mathrm{Y}_{\mathrm{i}}$ & -0.82 & -0.012 \\
$\mathrm{Y}_{\text {floc }} \mathrm{Y}_{\mathrm{NaCl}}$ & -1.06 & 0.008 \\
$\mathrm{Y}_{\mathrm{i}} \mathrm{Y}_{\mathrm{NaCl}}$ & -2.66 & -0.588 \\
\hline
\end{tabular}

Table 5: Analysis of variance (ANOVA) for percentage oil removal and energy consumption.

\begin{tabular}{|l|c|c|}
\hline Statistical analysis & $\begin{array}{c}\text { Oil removal } \\
\text { percentage }\end{array}$ & $\begin{array}{c}\text { Energy consumed } \\
\left(\mathbf{k W}-\mathbf{h} / \mathbf{m}^{\mathbf{3}}\right)\end{array}$ \\
\hline Explained variance (\%) & 87.10 & 99.98 \\
Correlation coefficient & 0.933 & 0.999 \\
Calculated F-value & 12.37 & $32,938.95$ \\
Tabulated F-value (CI = 95\%) & 3.09 & 3.49 \\
Calculated F/Tabulated F & 4 & $9,437.82$ \\
\hline
\end{tabular}

The statistical models expressed by equations (2) and (3) were generated, representing where percentage oil removal and energy consumption as a function of the variables, where the more significant are in boldface, respectively. Because the calculated F-value is higher than the tabulated F-value, both equations are statistically significant and useful for predictive purposes.

$$
\begin{aligned}
& \% \mathrm{R}=(66.01173 \pm 4.347866)+ \\
& (0.024325 \pm 0.005016) \times[\mathrm{oil}]+ \\
& (0.08484 \pm 0.020761) \times \mathrm{i}+ \\
& (0.00063 \pm 0.000155) \times[\mathrm{NaCl}]- \\
& \left(4 \times 10^{-5} \pm 1.6 \times 10^{-6}\right) \times[\mathrm{oil}] \times \mathrm{i} \\
& \mathrm{EC}=-(0.266295 \pm 0.025450)+ \\
& (0.024325 \pm 0.000153) \times \mathrm{i}+ \\
& \left(4 \times 10^{-6} \pm 1 \times 10^{-6}\right) \times[\mathrm{NaCl}]
\end{aligned}
$$

Inspection of the values shown in Table 5 reveals that both the dependence of the percentage oil removal and EC response are more complicated than can be described by just two principal effect values alone.

If $\mathrm{X}_{\text {floc }}$ does not really affect percentage oil removal, one can expect the results for experiments 1 and 3, 2and $4 \ldots 14$ and 16 to be the same within experimental error, since these pairs of experiments have identical conditions for $X_{o i l}, X_{i}$ and $X_{\mathrm{NaCl}}$. Inspection of the values in Table 2 confirms this observation. The variation in percentage oil removal is shown as a function of the interaction variables current density and oil and electrolyte $(\mathrm{NaCl})$ concentrations. Data in Table 2 may also be plotted with each axis corresponding to one factor. Figure 2 confirms the simple behaviour for \% oil removal values.

\section{$\mathbf{X}_{\text {oil }}$ Parameter}

Comparing pairs of experiments where only values of the $\mathrm{X}_{\mathrm{oil}}$ differs, for example, runs 1 and 2, 3 and 4 , etc. The value of percentage oil removal, increases when $X_{\text {oil }}$ is at its highest level, i.e., this factor has a positive effect. The value of percentage oil removal increase with a change of $200 \mathrm{ppm}$ to $1050 \mathrm{ppm}$. The absolute value of percentage oil removal increases to approximately $17.2 \%$ for $\mathrm{X}_{\mathrm{i}}=19.48$ A.m ${ }^{-2}, \mathrm{X}_{\mathrm{NaCl}}=15,000 \mathrm{ppm}$ and this is independent of $\mathrm{X}_{\mathrm{floc}}$. Similar behavior is also observed when the $X_{\mathrm{NaCl}}=35,000 \mathrm{ppm}$, except for a smaller increase of about $6.59 \%$ oil removal occurs. This difference of about $10 \%$ is independent of $\mathrm{X}_{\text {oil }}$ and this behavior may be attributed to the ratio of amount of oil to that of smaller bubbles, which improves removal efficiency. 


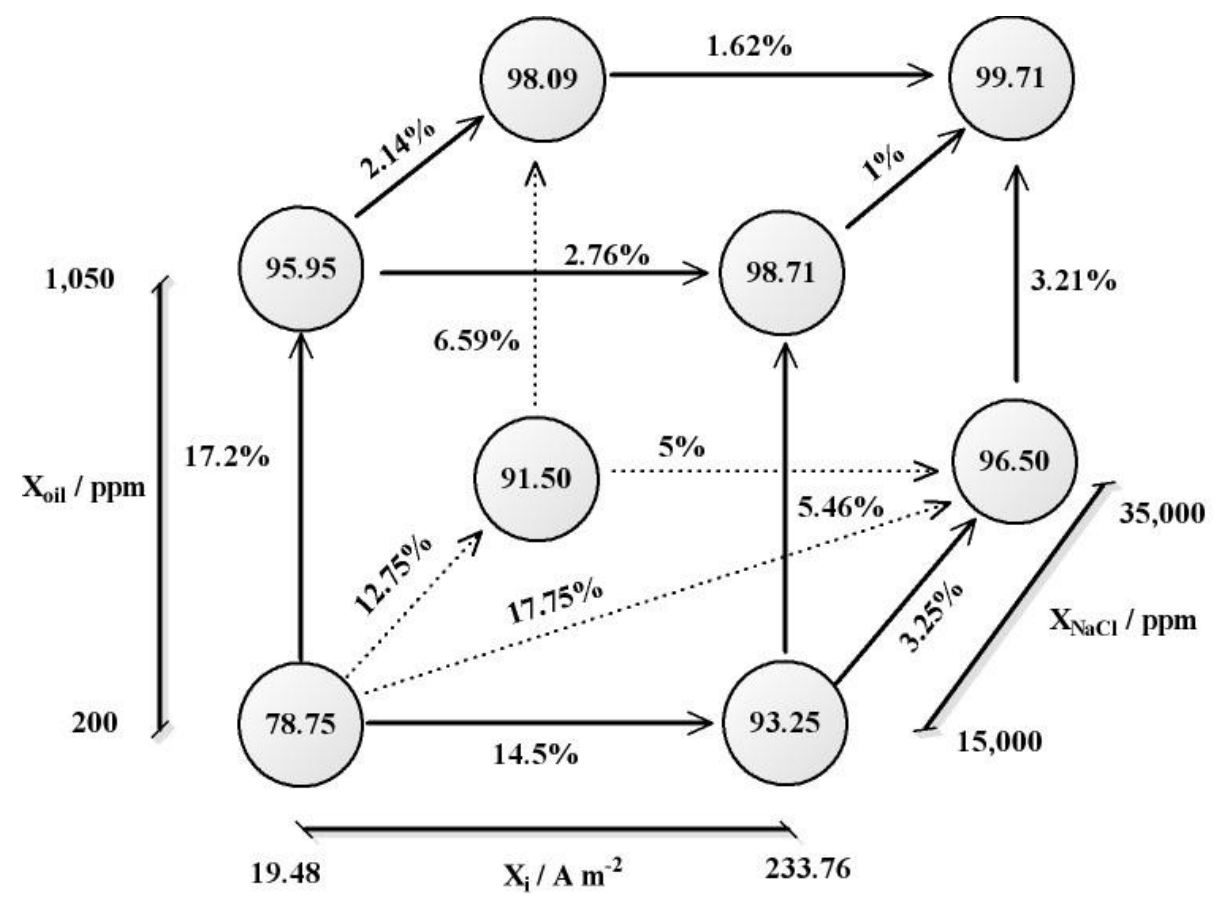

Figure 2: $2^{4}$ factorial design diagram for the average values of percentage for oil removal responses.

\section{$\mathbf{X}_{\mathbf{i}}$ Parameter}

On comparing pairs of experiments that differ only by $X_{i}$, for example runs 1 and 5, 2 and 6 , etc, the percentage oil removal values increase with a change in amount of gas production - 19.48 A.m ${ }^{-2}$ to 233.76 A. $\mathrm{m}^{-2}$ current density. This is consistent with the value of the positive main effect for $Y_{i}$ in Table 4. In other words, the percentage oil removal response is dependent on current density. The absolute value of percentage oil removal increases approximately $14.5 \%$ when the density current is changed, $X_{\mathrm{oil}}$ is $200 \mathrm{ppm}$ and $\mathrm{X}_{\mathrm{NaCl}}$ is $15,000 \mathrm{ppm}$, irrespective of the value of $X_{\text {floc }}$. Similar behavior is also observed when $X_{\mathrm{NaCl}}$ is $35,000 \mathrm{ppm}$, except for a small increase of about $5 \%$ in percentage oil removal. This difference of about $9.5 \%$ is independent of $\mathrm{X}_{\mathrm{floc}}$ and can probably be explained by the fact that the salt $(\mathrm{NaCl})$ decreases the size of the bubbles. In this case, it is necessary a high current density to produce the rupture of the linking of emulsified oil drops in a bigger volume of dispersant. However, when the oil concentration is higher than $1050 \mathrm{ppm}$, the rupture becomes easier to low current density (19.48 A.m $\left.{ }^{-2}\right)$ due to the existence of a bigger interaction contact surface between the gas bubble-oil particle.

The amount of bubbles electrochemically generated is significant when the salt concentration increases to $35,000 \mathrm{ppm}$, the size of bubbles diminishes and the bubble contribution is reduced to 9\% in this case indicating that the size of bubbles is an important factor in producing a larger active contact area between the bubbles and oil drops.

\section{$\mathbf{X}_{\mathrm{NaCl}}$ Parameter}

Comparing pairs of runs that differ only by $\mathrm{X}_{\mathrm{NaCl}}$, runs 1 and 9,2 and 10, etc. the percentage oil removal value increase when $\mathrm{X}_{\mathrm{NaCl}}$ is at its highest level, i.e., this factor has a positive effect corresponding to $\mathrm{Y}_{\mathrm{NaCl}}$ Table 4. This is an important characteristic due to the reduction in bubble size.

Figure 2 shows that interaction effect between current density and salinity is very significant for the following reasons. According to Burns et al. (1997) and Hosny et al. (1996), a high $\mathrm{NaCl}$ concentration reduces the size of bubbles (especially of hydrogen), thereby increasing removal efficiency. High salinity increases the ionic force and reduces the thickness of the double layer, favor the agglomeration of drops and improves contact bubbles generated electrolytically. In this case a reduced bubble volume or a small buoyancy force of the bubble is necessary to break the weak superficial tension of water produced by high salinity. In addition, as the amount of gas increases with current density more oil drops 
can be collected, and in the present work, the percentage oil removal goes from $78.7 \%$ to approximately $96.50 \%$.

The factorial design diagram show in Fig 3 is also useful for choosing optimal conditions. In the present case, there is a optimal region between 220 and 260 A $\mathrm{m}^{-2}$ and 14000 and $24000 \mathrm{ppm}$ of $\mathrm{NaCl}$ that produces a better percentage oil removal than the initial concentration of $1050 \mathrm{ppm}$. These conditions were found to have the best performance in the present work.

\section{Energy Consumption}

Energy consumption EC $\left(\mathrm{kwh}^{-3}\right)$ was calculated with the following equation:

$$
\mathrm{EC}=\frac{\mathrm{UI}}{\mathrm{Q}_{\mathrm{V}} 1000}
$$

where $\mathrm{U}$ is the cell potential; I, the electrolysis current; and $\mathrm{Q}_{\mathrm{v}}$, the volumetric flow rate, $\mathrm{m}^{3} \mathrm{~h}^{-1}$.

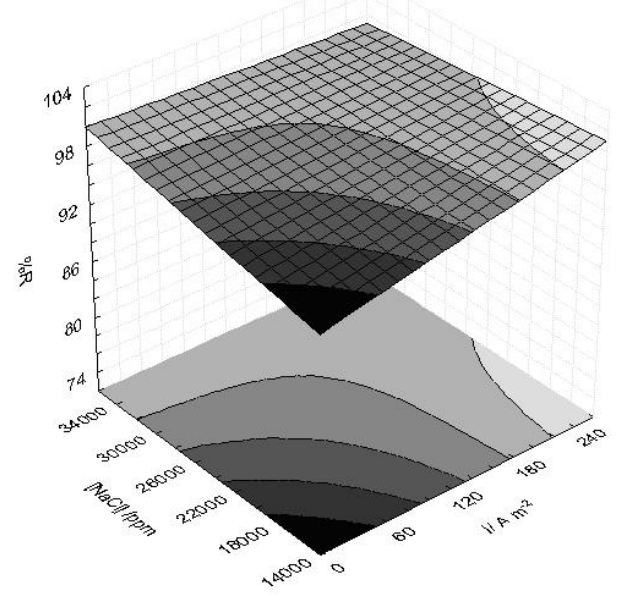

Figure 3: Response surfaces for percentage oil removal: Effects of $\mathrm{i}$ and $[\mathrm{NaCl}]$ $([$ oil $]=1050 \mathrm{ppm})$.
In Figure 4 it is shown that energy consumption varied from 0.48 to $4.5 \mathrm{kwh} \mathrm{m}^{-3}$ in a current density range of 19.48 to $233.76 \mathrm{~A} \mathrm{~m}^{-2}$, when the salt concentration was at the minimum. For a salt concentration around the maximum value, of energy consumption varied from 0.48 to $4.0 \mathrm{kwh} \mathrm{m}^{-3}$, between the minimum and maximum current densities. The same effect was also identified by Chen et al. [2000; 2002]. Using a salt concentration of approximately 39000 ppm Hosny [1992; 1996] obtained an energy consumption of $2.66 \mathrm{kwhm}^{-3}$ applying $100 \mathrm{Am}^{-2}$, in an electroflotation cell with lead anodes.

The energy consumed to remove $100 \%$ of the oil calculated by equation (3) in the present work is about $13 \%$ lower than that obtained by Hosny [1996] to remove $75 \%$ with the same current density utilized, as shown in Table 6. This difference can be attributed to the DSA utilized that has better electrocatalytic properties and consequently a lower oxidation potential than the lead anode to produce chlorine gas.

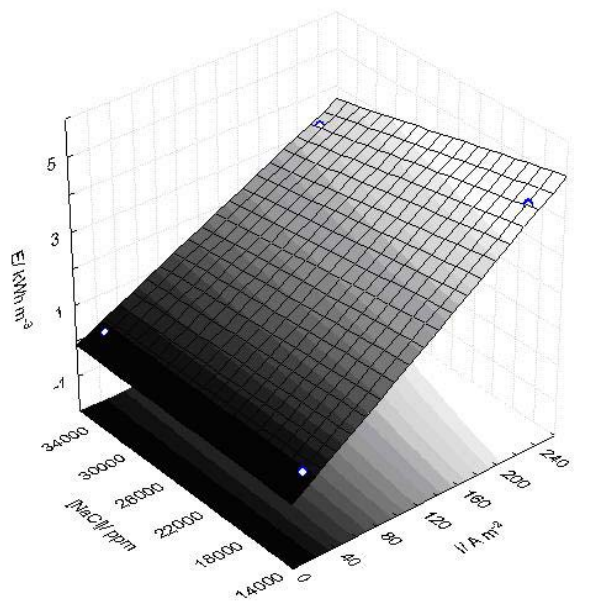

Figure 4: Response surfaces on energy consumption: Effects of $\mathrm{i}$ and $[\mathrm{NaCl}]([\mathrm{oil}]=625 \mathrm{ppm}$,

$[$ floc $]=18 \mathrm{ppm})$.

Table 6: Present results compared with those of another author [Hosny, 2006].

\begin{tabular}{|l|r|r|}
\hline & Hosny & Present work \\
\hline$[\mathrm{NaCl}], \mathrm{ppm}$ & 39,000 & 35,000 \\
$\mathrm{CE}, \mathrm{kWh} / \mathrm{m}^{2}$ & 2.66 & 2.38 (Eq. 2) \\
$\mathrm{i}, \mathrm{A} / \mathrm{m}^{2}$ & 100 & 100 \\
$\% \mathrm{R}$ & 75 & 100 (Eq. 3) \\
{$[\mathrm{oil}], \mathrm{ppm}$} & 1050 & 1050 \\
$\mathrm{pH}$ of emulsion & 4.5 & 4.5 \\
Electrode gap, cm & 1.5 & 1.5 \\
Electrode & $1 \mathrm{ead}$ & DSA \\
Time of electrolysisis, min & 40 & 30 \\
\hline
\end{tabular}




\section{CONCLUSIONS}

The rate of oil drop flotation was improved for smaller bubbles. The agglomeration of oil drops by contact with ascending gas was better with microbubbles due to the large surface area of contact. Oil removal by electroflotation was strongly affected by initial concentration, increasing the conversion from 78.70 to $95.90 \%$. The increase in current density and salinity improved oil removal. With the experiments, it was proved that it is possible to remove about $99 \%$ of the oil using a current density of $19.40 \mathrm{Am}^{-2}$ with an energy consumption of $0.167 \mathrm{kw}-\mathrm{hm}^{-3}$.

\section{NOMENCLATURE}

$\begin{array}{llr}\text { EC } & \text { energy consumption } & \begin{array}{r}\mathrm{kWh} / \mathrm{m}^{3}, \\ \text { equation (3) }\end{array} \\ \mathrm{I} & \text { Electric current } & \mathrm{A} \\ \% \mathrm{R} & \text { percentage oil removal } & \% \text {, equation (2) } \\ \mathrm{X} & \text { input variables } & (-) \\ \mathrm{X}_{\mathrm{oil}}, & \text { oil concentration } & \mathrm{ppm} \\ \mathrm{X}_{\text {floc }}, & \text { flocculent concentration } & \mathrm{ppm} \\ \mathrm{X}_{\mathrm{NaCl}} & \text { electrolyte concentration } & \mathrm{ppm} \\ \mathrm{X}_{\mathrm{i}} & \text { current density } & \mathrm{A} / \mathrm{m}^{2} \\ \mathrm{Y}_{\mathrm{i}} & \text { the predicted response } & (-) \\ \beta_{0} & \text { offset term } & \text { equation }(1) \\ \mathrm{i} & \text { Coefficient } & \text { equation }(1) \\ \mathrm{j} & \text { Coefficient } & \text { equation }(1)\end{array}$

\section{ACKNOWLEDGEMENTS}

The authors wish to thank PROSET/CTpetro/CNPq and PRODOC/CAPES for their financial support of this work. We also thank Msc. M.F.Vieira (CTCC/SENAI-PB) for helping with analysis of the oil and Oxiteno S.A. and Petrobras for suppling the Tween 20 emulsifier and flocculant, respectively.

\section{REFERENCES}

Al-Shamrani, A. A., James, A. and Xiao, H., Destabilization of Oil-Water Emulsions and
Separation by Dissolved Air Flotation, Water Research, 36 (6), 1503-1512 (2002).

Al-Shamrani, A. A., James, A. and Xiao, H., Separation of Oil from Water by Dissolved Air Flotation, Colloids and Surfaces A: Physicochemical and Engineering Aspects, 209 (1), 15-26 (2002).

Barros, N. B., Scarminio, I. S. and Bruns, R. E., Planejamento e Otimização de Experimentos, Editora da Unicamp, São Paulo (1996).

Ben Mansur, L. and Chalbi, S., Remove of Oil from Oil/Water Emulsions using Electroflotation Process, Journal of Applied Electrochemistry, 36, 577-581 (2006).

Burns, S. E., Yiacoumi, S. and Tsouris, C., Microbubble Generation for Environmental and Industrial Separations, Separation and Purification Technology, 11, 221-232 (1997).

Calvin, P. C. P., Electroflotation for Groundwater Decontamination, Journal of Hazardous Materials, 55, 150-170 (1997).

Chen, X. Chen, G. and Yue, P. L., Investigation on the Electrolysis Voltage of Electrocoagulation, Chemical Engineering Science, 57, 2449-2455 (2002).

Chen, X., Chen, G. and Yue, P. L, Separation of Pollutants from Restaurant Wastewater by Electrocoagulation, Separation and Purification Technology, 19, 65-76 (2000).

Hosny, A. Y., Separation of Oil from Oil/Water Emulsions Using an Electroflotation Cell with Insoluble Electrodes, Filtration \& Separation, 29 (5), 419-423 (1992).

Hosny, A. Y., Separation of Oil from Oil/Water Emulsions by electroflotation technique, Filtration \& Separation, 6 (1), 9-17 (1996).

Khosla, N. K., Venkatachalam, S. and Somasundaran, P., Pulsed Electrogeneration of Bubbles for Electroflotation, Journal Appl. Electrochem, 21, 986 (1991).

Koren, J. P. K. and Syversen, U., State-of-the-Art Electroflocculation, Filtration \& Separation, 32 (2), 153-156 (1995).

Rodrigues, M. I. and Lemma, A. F., Planejamento de Experimentos e Otimização de Processos: Uma Estratégia Seqüencial de Planejamentos, Casa do Pão Editora, São Paulo, 2005. 